\title{
Verzeichnis \\ der Herren, welche für den elften Band Referate geliefert haben.
}

(Die Verantwortlichkeit für den Inhalt der Referate tragen die Herren Referenten. Die in Klammern gesetzten Chiffern bezeichnen die Uebersetzer der in fremder Sprache eingesandten Referate).

A. Herr Prof. A ugust in Berlin.

B. - Prof. Bruns in Berlin.

Bcki. - Prof. Baraniecki in Warschau.

Bg. - Prof. Björling in Land.

Bj. - Prof. Bjerknes in Christiania.

B.K. - Dr. B. Klein in Giessen.

Bl. - Prof. Brill in München.

Bo. - Dr. Biermann in Berlio.

Bw. - Prof. Bobylew in Petersburg.

Cly. - Prof. Cayley in Cambridge.

Csy. - Prof. Casey in Dublin.

Do. - Dickstein in Warschau.

G. - Prof. v. Geer in Leiden.

Glr. - Prof. Glaisher in Cambrídge.

Gm. - Dr. Gram in Kopenbagen.

Gr. - Prof. Günther in Ansbach.

H. - Prof. Hoppe in Berlin.

Hr. - Dr. Hamburger in Berlin.

H.St. - H. Stahl in Berlin.

L. - Prof. Lie in Christiania.

Ls. - Lazarus in Hamburg.

M. - Dr. F. Müller in Berlin.
Mi. Herr Dr. Micbaelis in Berlin.

M-L. - Prof. Mittag-Leffler in

Stockholm.

Mn. - Prof. Mansion in Gent.

Mz. - Dr. Maynz in Ludwigslust.

No. - Prof. Netto in Strassburg.

Nr. - Prof. Nöther in Erlangen.

0. - Dr. 0 brtmann in Berlin.

0k. - Prof. Oberbeck in Halle a.S.

P. - Dr. v. Posse in Petersburg.

Rs. - Dr. Rosochatius in Berlin.

Sch. - Prof. Schering in Göttingen.

Scbg. - Dr. Schlegel in Waren.

Schl. - Dr. Schemmel in Berlin.

Schn. - Dr. Schumann in Berlin.

Scht. - Dr. Schubert in Hamburg.

Sm. - Prof. Sturm in Münster i. W.

St. - Prof. Stolz in Inosbruck.

Std. - Prof. Studnička in Prag.

T. - Dr. Toeplitz in Breslau.

v. - Prof. Voss in Dresden.

Wn. - Prof. Wangerin in Berlin.

Briefe und Zusendungen erbitten wir entweder durch Vermittelung der Verlagshandlung oder unter der Adresse:

Dr. C. Ohrtmann, Berlin SW, Markgrafenstr. 78. III. 